The International Journal of Indian Psychology

ISSN 2348-5396 (e) | ISSN: 2349-3429 (p)

Volume 5, Issue 1, DIP: 18.01.120/20170501

DOI: $10.25215 / 0501.120$

http://www.ijip.in | October-December, 2017

Original Research Paper

\title{
Impact of Sexual Abuse on Self-Esteem and Psychological Well- Being of Adolescent Girls
}

\author{
John Jacob. $\mathrm{M}^{1}$, Dr. Vidhya Ravindranadan ${ }^{2}$
}

\section{ABSTRACT}

Child sexual abuse is a universal problem that occurs across gender, caste, color, religion, ethnic and socio-economic group. Sexual abuse creates intense trauma and emotional problems which create serious short term and long term psychological and behavioural problems.81.53\% of the total incidence of child sexual abuse was reported amongst children between 11 and 18 years of age. The pre-adolescent to the adolescent child seems to be most at risk (Kacker, Varadan, Kumar, 2007). The present study intends to assess the impact of sexual abuse on self esteem and psychological well being of adolescent girls. Sample consists of 75 adolescent girls aged 12-18 years. 25 sexually abused girls from rehabilitating government children's home, 25 non-abused girls from a destitute home for children and 25 girls staying with parents. Instruments used are Self-Esteem Scale (SES-DSDU) and Psychological Well-Being Scale (PWBS-SDCP). The results indicate the sexual abuse has a significant impact on self esteem and psychological well-being of adolescent girls.

Keywords: Sexual Abuse, Adolescent, Self- Esteem, Psychological Well-being

Adolescence is typically viewed as the preparation for adulthood. The term adolescence comes from the Latin word 'Adolescere', meaning 'to grow' or 'to grow to maturity'. The term adolescence has a broader meaning. It includes mental, emotional, social as well as physical maturity. The most commonly used chronologic definition of adolescence includes children from the age group of 10-18, but may incorporate a span of 9 to 26 years depending on the source (APA, 2002).

Adolescence, the second decade of life, is a period in which an individual undergoes major physical and psychological changes. There are enormous changes in the person's social interactions and relationships. Adolescence is a time of opportunity, but also one of risk. Finding self identity is the central characteristics of adolescence. Physical and sexual abuse of adolescents is becoming a major health problem. In infants, the sex distribution is

\footnotetext{
${ }^{1}$ Research Scholar, Department of Research and Development, Bharatiar University, Coimbatore, Tamil Nadu, India

${ }^{2}$ Assistant Professor, Department of Psychology, Union Christian College, Aluva, Kerala, India

*Responding Author

(c) 2017 John J K \& Ravindranadan V; licensee IJIP. This is an Open Access Research distributed under the terms of the Creative Commons Attribution License (www.creativecommons.org/licenses/by/2.0), which permits unrestricted use, distribution, and reproduction in any Medium, provided the original work is properly cited.
} 
approximately equal, but adolescent females are twice as likely to be abused as adolescent males, largely because of the frequency of sexual abuse. According to the study by Stock, Bell, Boyer, and Connell (1997), adolescent girls who had been sexually abused are more likely than non-abused girls to be sexually active and to engage in risky sexual behavior. Abuse of girls is usually kept hidden under the guise of family honor and issue of 'purity' while in the case of boys, they are often ignored. But the recent awareness against sexual abuse has created an atmosphere of reporting to the authorities. An earlier study conducted in Kerala proved that girl children were victims of contact abuse more (26.02\%) in comparison to boys (14.06\%) (Nair, Devika J., 2014).

The word 'Abuse' is based on a Latin word “abusus" meaning 'misused'. The United Nations has defined child sexual abuse as contacts or interactions between a child and an older or more knowledgeable child or adult (a stranger, sibling or person in position of authority, a parent or a caretaker) when the child is being used as an object of gratification for the older child's or adult's sexual needs. These contacts or interactions are carried out against the child using force, trickery, bribes, threats or pressure (UNICEF, 2003). Child sexual abuse is classified into Type I (contact abuse) Type II (non contact abuse) as Peters classification. Type I involves penetration abuse like rape and sodomy as well as touching and fondling of genitals etc. Type II involves exposing the child to pornography, talking sexually explicit things and exhibitionism in front of the child (Barth J, Bermetz I. 2013).

Self-esteem is related to feelings and thinking of one individual about his own value and competencies, which reflect a positive or negative attitude about himself (Rosenberg, 1965). Self Esteem refers to individual's sense of value or worth or the extent to which a person values, approves of, appreciates, prizes or likes himself/herself.

Well being is one of the most important goals which individuals as well as societies strive for. The term denotes that something is in a good state. Psychological well-being is the subjective feeling of contentment, happiness, satisfaction with life experience and of one's role in the work, sense of achievement, utility, belongingness, and no distress, dissatisfaction or worry etc. These things are difficult to evaluate objectively. Hence the emphasis is on the term subjective well being. Also, research studies conducted by Garnefski and Arends, (1998); Garnefski and Diekstra, (1997); etc. have consistently found that adolescent survivors of child sexual abuse report greater depression and general psychological distress, more conduct problems and aggression, lower self-esteem, and more substance abuse problems. This reflects that the adolescent's psychological well-being is affected.

\section{Hypothesis:}

1. There will be significant mean difference on self-esteem among three study groups.

2. There will be significant mean difference on psychological well-beingamong three study groups. 


\section{METHOD}

\section{Objective:}

- To understand the impact of sexual abuse on the self esteem and psychological wellbeing of institutionalized and non-institutionalized adolescent girls.

\section{Sample:}

The sample consists of 75 adolescent girls of age group 12-18 years. The study was conducted in the state of Kerala in India among three different groups of 25 each. The first sample group was randomly selected from sexually abused girls staying in children's home, Kerala State. The $2^{\text {nd }}$ sample group was selected from non-abused girls staying in destitute homes. The $3^{\text {rd }}$ group was non-abused children staying with own parents at home. All the three groups come from low socio-economic group.

\section{Instruments:}

1. Self Esteem Scale SES-DSDU was developed by Dr. Santosh Dhar and Dr. Upinder Dhar (2015). A 23-item scale measures global self-worth by measuring both high and low feelings about the self. All items are answered using a 5-point Likert scale format ranging from strongly agree to strongly disagree with a view to measure several factors such as positivity, openness, competence, humility, self-worth and learning orientation. Each item which is checked as strongly disagree, disagree, not sure, agree or strongly agree is awarded the score 1,2,3,4 and 5 respectively. Higher the total score, higher the self-esteem. The scoring scale is 98 and above $=$ High, 81-97 $=$ Normal and 80 and below $=$ Low .

2. Psychological Well-Being Scale PWBS-SDCP was developed by Dr. Devendrea Singh Sisodia and Ms. Pooja Choudhary (2012). This scale was developed by using Likert technique. The final form of scale was prepared comprising of 50 statements with a view to measure several aspects of wellbeing like satisfaction, efficiency, sociability, mental health and interpersonal relations. This scale is considered likely to be useful in a variety of research and applied settings such as a quality of life index, a mental health status appraisal, and a measure of psychotherapy outcome evaluation and a social indicator of measuring population changes in the sense of well-being over time. The scoring scale is: 50-58=Very low, 58-83= Low, 84- 217= Moderate, 217- 242= High and 242-250=Very High

\section{Statistical Analysis:}

Data were analyzed using SPSS; ANOVA and Post-Hoc test have been conducted to verify the hypothesis.

\section{RESULTS AND DISCUSSION}

TABLE 1 - Result of ANOVA of the study groups on Self Esteem and Psychological WellBeing.

\begin{tabular}{|l|l|r|r|r|r|r|}
\hline Variables & \multicolumn{1}{c|}{$\begin{array}{c}\text { Sum of } \\
\text { Squares }\end{array}$} & \multicolumn{1}{c|}{ df } & \multicolumn{1}{c|}{$\begin{array}{c}\text { Mean } \\
\text { Square }\end{array}$} & \multicolumn{1}{c|}{ F } & \multicolumn{1}{c|}{ Sig. } \\
\hline \multirow{2}{*}{ Self-Esteem } & $\begin{array}{l}\text { Between } \\
\text { Groups }\end{array}$ & 26130.605 & 2 & 13065.303 & 72.343 & .000 \\
\cline { 2 - 7 } & Within & 12822.800 & 71 & 180.603 & & \\
\hline
\end{tabular}

(c) The International Journal of Indian Psychology, ISSN 2348-5396 (e)| ISSN: 2349-3429 (p) | 189 
Impact of Sexual Abuse on Self-Esteem and Psychological Well-Being of Adolescent Girls

\begin{tabular}{|c|c|c|c|c|c|c|}
\hline Variables & & $\begin{array}{l}\text { Sum of } \\
\text { Squares }\end{array}$ & df & $\begin{array}{l}\text { Mean } \\
\text { Square }\end{array}$ & $\mathbf{F}$ & Sig. \\
\hline & Groups & & & & & \\
\hline & Total & 38953.405 & 73 & & & \\
\hline \multirow{3}{*}{$\begin{array}{l}\text { Psychological } \\
\text { Well-Being }\end{array}$} & $\begin{array}{l}\text { Between } \\
\text { Groups }\end{array}$ & 131426.613 & 2 & 65713.307 & 108.837 & .000 \\
\hline & $\begin{array}{l}\text { Within } \\
\text { Groups }\end{array}$ & 42868.265 & 71 & 603.778 & & \\
\hline & Total & 174294.878 & 73 & & & \\
\hline
\end{tabular}

From table 1, The ANOVA results show that there is a significant mean difference in selfesteem and psychological well-being among the groups. The three study groups have significantly different mean on the variables. In order to understand which group means are statistically significant, post hoc-test has been done and the results are given in Table 2.

TABLE 2: Results of post-hoc test on self-esteem among the groups.

\begin{tabular}{|l|l|l|l|l|}
\hline \multirow{2}{*}{ Grp } & \multirow{2}{*}{$\mathbf{N}$} & \multicolumn{3}{|l|}{ Subset for alpha $=\mathbf{0 . 0 5}$} \\
\cline { 3 - 5 } & & $\mathbf{1}$ & $\mathbf{2}$ & $\mathbf{3}$ \\
\hline 1 & 25 & 49.64 & & \\
\hline 2 & 25 & & 60.28 & \\
\hline 3 & 24 & & & 94.00 \\
\hline Sig. & & 1.000 & 1.000 & 1.000 \\
\hline
\end{tabular}

The results given in Table 2 indicate that the self-esteem of 3 groups is significantly different from each other. The $1^{\text {st }}$ group (sexually abused living in children's home) has the lowest mean score of 49.64 in self esteem than the non-abused institutionalized children and the children that stay at home. The $2^{\text {nd }}$ group of non-abused institutionalized children has lower mean score of 60.28 in self esteem compared to the $3^{\text {rd }}$ group of non-abused children staying with parents, who have a mean score of 94 which is the highest score. There is a significant difference in the level of Self-Esteem among Group 1(Sexually Abused Institutionalized Children) and Group 2 (Non-Abused Institutionalized Children) and Group 3 (Normal counterparts). It can be assumed that sexual abuse has negative impact on the self-esteem of adolescent girls. Thus it can be seen that sexual abuse, institutionalization and lack of parental care have negative impact on the self-esteem of adolescent girls.

TABLE: 3 Results of post hoc test on psychological well-being among the groups.

\begin{tabular}{|l|l|l|l|l|}
\hline \multirow{2}{*}{ Grp } & \multirow{2}{*}{$\mathbf{N}$} & \multicolumn{3}{|c|}{ Subset for alpha = 0.05 } \\
\cline { 3 - 5 } & & $\mathbf{1}$ & $\mathbf{2}$ & \multicolumn{1}{|c|}{$\mathbf{2}$} \\
\hline 1 & 25 & 96.12 & & \\
\hline 2 & 25 & & 133.40 & 198.63 \\
\hline 3 & 24 & & & 1.000 \\
\hline Sig. & & 1.000 & 1.000 & \\
\hline
\end{tabular}




\section{Impact of Sexual Abuse on Self-Esteem and Psychological Well-Being of Adolescent Girls}

The $1^{\text {st }}$ group of children who are sexually abused has a mean score of 96.12 which means moderate psychological well-being but the level of psychological well-being is lower than the other 2 groups. The $2^{\text {nd }}$ group of non-abused children in institution has a moderate mean score of 133.40 in psychological well-being but lower than children staying at home. The $3^{\text {rd }}$ group of non-abused children staying with parents have moderate mean score of 198.63 but significantly higher psychological well-being when compared to other groups. Post Hoc result shows that there is significant difference in the level of Psychological Well-Being between Group 1 (Sexually Abused Institutionalized Children) and Group 2 (Non-Abused Institutionalized Children). It can be noted that sexual abuse has negative impact on the psychological well-being of adolescent girls. There is a significant difference in the level of Psychological Well-Being between Group 2 (Non-Abused Institutionalized Children) and Group 3 (Normal Children living with Parents). The difference between these two groups is that Group 2 is institutionalized and lack parental care. Thus, sexual abuse, institutionalization and lack of parental care have negative impact on the psychological wellbeing of adolescent girls.

Significantly lower self-esteem and psychological well-being were observed in sexually abused institutionalized girls than non-abused institutionalized adolescent girls and normal counterparts staying at home. Thus, sexual abuse has significant impact on self-esteem and psychological well-being of adolescent girls. The result implies that the children in institution especially abused children need serious psychological intervention to enhance self-esteem and psychological well-being.

\section{Acknowledgments}

The author appreciates all those who participated and assisted in the study to facilitate the research process.

Conflict of Interests: The authors declare that there are no potential conflicts of interest with respect to the research, authorship, and/or publication of this article.

\section{REFERENCES}

APA (2002). Developing adolescents: A reference for professionals. Washington, DC: American Psychological Society

Barth J, Bermetz I, Heim E, Trelle S, Tonia T. The current prevalence of child sexual abuse worldwide: a systematic review and meta-analysis.Int J Public Health. 2013 Jun;58(3):469-83

Blascovich, J. and Tomaka, J (1991). Measures of Self- Esteem. Measures of personality and social psychological attitudes, 1, 115-160.

Bung-Nyun Kim, Subin Park and Min-Hyeon Park. The Relationship of Sexual Abuse with Self-Esteem, Depression, and Problematic Internet Use in Korean Adolescents, Psychiatry Investigation. 2017 May; 14(3): 372-375.

Dhar, S and Dhar, U. 2005. Manual for Self Esteem Scale; National Psychological Corporation. KacheriGhat, Agra. 


\section{Impact of Sexual Abuse on Self-Esteem and Psychological Well-Being of Adolescent Girls}

Finkelhor, D., Sahttuck, A., Turner,H. A., Hambly, S.L.( 2014). The Lifetime Prevalence of Child Sexual Abuse and Sexual Assault assessed in Late Adolescence. Journal of Adolescent Health. Vol: 55(3). pp: 329-33.

Garnefski, N. \& Diekstra, R.F. (1997). Child sexual abuse and emotional and behavioral problems in adolescence: gender differences. Journal of American Academy of Child and Adolescent Psychiatry, 36(3), 323-329

Garnefski, N., \&Arends, E. (1998). Sexual abuse and adolescent maladjustment: Differences between male and female victims. Journal of Adolescence, 21(1), 99- 107

Kacker,L, Srinivas, V\& Kumar, P. Study on Child Abuse; India 2007. Ministry of Women and Child Development. Government of India.

Nair, B.A and Devika, J. (2014) Self - reported sexual abuse among a group of adolescents attending life skills education workshops in Kerala. Academic Medical Journal of India. Vol II- Issue 1.

Rosenberg, M. (1965). Society and the adolescent self-image. Princeton, NJ: Princeton University Press.

Sisodia, D.S and Choudhary, P. 2005. Manual for Psychological Well Being Scale; National Psychological Corporation. KacheriGhat, Agra.

Srednicki-R,O and Twaite, J, A. (2006). Understanding, assessing and treating adult victims of childhood abuse. Jason Aronson. USA

Stock, J., M., Boyer, D., and Connell, F.1997. Adolescent pregnancy and sexual risk taking among sexually abused girls. Family Planning Perspective 29: 200-203

Tripatithy, S.N. (2003). Girl child in India. Discovery publishing house. P 12-13.

How to cite this article: John J K \& Ravindranadan V (2017). Impact of Sexual Abuse on Self-Esteem and Psychological Well-Being of Adolescent Girls. International Journal of Indian Psychology, Vol. 5, (1), DIP: 18.01.120/20170501, DOI: 10.25215/0501.120 